\title{
RUNNING UP OR DOWN: WHY IS THERE A DIFFERENCE IN SPENDING?
}

\author{
Martinette Kruger* \\ North-West University \\ Martinette.Kruger@nwu.ac.za
}

Received: November 2013

\author{
Melville Saayman\# \\ North-West University \\ Melville.Saayman@nwu.ac.za \\ Accepted: January 2015
}

\begin{abstract}
This study investigated the determinants of participant spending at the Comrades Marathon 'up' run (Durban to Pietermaritzburg) and 'down' run (Pietermaritzburg to Durban). A participant survey conducted at the race in 2011 and 2012, using regression analyses, found that more behavioural than socio-demographic determinants had a significant influence on spending at both races. The two groups of participants had very similar profiles, but their spending at the event differed significantly in the way it was distributed between the 'up' and 'down' runs, and the spending was higher at the former. The reasons for the difference are currently unknown, but the implication is that the 'up' and the 'down' runs may have different economic outcomes. Although this cannot be confirmed on the basis of surveys of just two years' Comrades runs, the findings could offer strategic insights for marketing the event and enhancing its economic impact and competitive advantage.
\end{abstract}

Keywords

Sport tourism, ultra-marathon, determinants of spending, regression analysis, Comrades Marathon, South Africa

*Prof M Kruger is an associate professor at TREES (Tourism Research in Economic Environs and Society), North-West University, Potchefstroom, South Africa.

\#Prof M Saayman is the Research Director of TREES (Tourism Research in Economic Environs and Society), North-West University, Potchefstroom, South Africa. 


\section{INTRODUCTION}

Sport and event tourism is big business. From its beginnings in small participatory events, it has expanded to mega and hallmark events viewed by millions worldwide (Saayman \& Saayman, 2006). Knowing how sport and event tourism can promote the country and generate income, in recent years South Africa has hosted events such as the British and Irish Lions Tour, the Indian Premier League Cricket, the Rugby Championship and Super 14 Rugby Tournaments, the Australian Cricket Tour, the FIFA Confederations Cup Soccer, the FIFA World Cup Soccer and the Africa Cup of Nations. Spectator sport is a growing segment of the leisure, recreation and tourism industries. More than 75 million US adults attend a sports event while travelling (TIA, 1999). The US Bureau of Economic Analysis estimates that Americans spent $\$ 6.7$ billion in 1997 attending sporting events, compared to $\$ 4.5$ billion in 1991 (BEA, 2000). Measuring total visitor spending, whether associated with a short-term event or year-round activity, is a frequent and important focus for tourism studies (Sun and Stynes, 2006). When other sport-related travel spending in the US is included, the economic impact of sport travel totals $\$ 27$ billion (TIA, 1999).

Since the first 'urban tour' marathon, the 1976 New York City Marathon, running-related tourism has snowballed globally (Burfoot, 2007). Originally referring to a race of 42 kilometres (26 miles), the term 'marathon' is now used more loosely for a variety of long-distance running races. Once limited largely to the Olympics and reserved primarily for the elite athlete who trained for serious competition, these races now come in many types - fun runs, half marathons, full marathons, ultra-marathons - to suit a wide range of competitors. The large numbers of participants and spectators mean that running tourism has become big business, with large sponsorships and media coverage, and increasing competition between host cities. Dozens of major cities organize marathons, and runners incur significant personal and financial costs to take part each year, with some events attracting over 15,000 participants (0gles \& Masters, 2003).

One such marathon is the Comrades, a world-renowned ultra-marathon of 89 kilometres (56 miles) that is run between the cities of Pietermaritzburg and Durban in South Africa. The race has been run every year since 1921, and has the special feature of alternating direction each year between the two cities, the so-called 'up' run (Durban to Pietermaritzburg) and the 'down' run (Pietermaritzburg to Durban). There are five notorious hills between these two cities, which means that the 'up' run is tougher, having approximately $56 \mathrm{~km}$ of positive gradient, compensated for slightly by the fact that the creators of the race made the route marginally shorter - about $86 \mathrm{~km}$ - because it takes runners longer to complete the race uphill.

Marathons such as the Comrades make a noticeable contribution to the local economy and total product offering of some destinations and countries (Pucher \& Buehler, 2007). Saayman and Saayman (2012) and Kruger, Saayman, Saayman and Rossouw (2011) found that the Comrades Marathon contributes significantly to the local economy (approximately R132 million or US\$132 00000 for the 'up' run in 2011 and R137 million or US\$137 00000 for the 'down run' in 2012) and supports more than 600 jobs. Visitor spending is one of the most critical variables of analysis for tourist destinations, as it directly indicates the tourism industry's, or a particular tourism sector's, profitability (Kastenholz, 2005). However, knowing the total amount that is spent on an event is not sufficient for marketing and planning purposes; it is essential also to identify and understand the variables that determine that spending (Saayman \& Saayman, 2012). 
To increase the spending by participating runners, it is important to establish the determinants of spending (Mok \& Iverson, 2000; Narayan, 2003; Letho et al., 2004; Kastenholz, 2005; Saayman \& Saayman, 2006; Van der Merwe et al., 2007). These determinants can assist marketers and event organizers in:

- marketing the destination,

- proposing alternative policies,

- developing a sustainable product,

- increasing product sales,

- improving customer service,

- defining markets, and

- creating a better understanding of the event.

Detailed knowledge of the determinants of participant spending can ultimately enhance the event's economic impact and give it a competitive advantage.

Since the 'up' and 'down' runs of the Comrades Marathon differ in intensity, the same factors may not be applicable or significant in both cases. It was therefore necessary to determine the most influential factors for participant spending at the two runs separately - to the authors' knowledge, this has not been done before. The aim of the study was therefore to investigate and compare the socio-demographic and behavioural determinants that influence participant expenditure at the 'up' and 'down' runs and to answer the following questions:

- Is spending higher at one of the two runs, and if so which one, and why?

- Is spending distributed differently at the 'up' and 'down' runs?

- Which socio-demographic, behavioural and travel motive determinants influence participant spending at the two runs?

- Which are the most influential determinants?

The answers will give organizers a comprehensive view of the variables that influence participant spending at the two different runs and increase the store of knowledge about competitors in marathons and running tourism in general.

\section{LITERATURE REVIEW}

Elected officials, their constituents and event organizers have become increasingly interested in sports tourism because sports events can generate media exposure, re-create the image of a destination, spread tourism geographically and seasonally, increase demand for local tourism, stimulate business and infrastructure development, attract investment, generate direct economic income, bring in tax revenue, create employment and offer benefits to the community (Saayman et al., 2008). In addition, these events allow a region, city or community to celebrate its uniqueness, promote itself, develop local pride and enhance its economic well-being. The economic benefit that visitor expenditure brings to the host community is one of the most important reasons for hosting an event in the first place (Kruger, 2009). 
For communities to benefit, it is important that tourists (in this case, the participating marathon runners) spend money in the local economy, since the total economic impact of an event is a function of their direct and indirect expenditure. Most of the current sports tourism research relates to major sports events that attract thousands of supporters of a team or individual athletes, such as football matches (Hill \& Green, 2000; Tapp \& Clowes, 2002; Giulianotti, 2002; Boen et al., 2005), ice hockey games (Bodet \& Bernace-Assollant, 2009), basketball games (Pan et al., 1997; Boen et al., 2008), professional golf tours (Crosset, 1995; McDonald et al., 2002; Robinson et al., 2004) and athletics meetings (Trail et al., 2003). This research has mainly focused on identifying the profiles and motives of the participants and supporters and the economic impact of the respective events. Research has been done on determinants of participant spending in several tourism sectors and areas, but not as yet, to the best of the authors' knowledge, on running tourism. Weed (2006) states that most sport tourism research concentrates on spectators rather than participants, and Mak (2004) observes that 'big gaps remain in our understanding of tourist spending behaviour'. Well-researched information about tourist expenditure is needed if we are to improve our understanding of the economic benefits of tourism for host communities.

The economic impact of a sporting event on a host region is primarily due to visitor spending (Cannon \& Ford, 2002). Tourist expenditure is thus the clearest indication of the economic benefits of tourism for an area (Mottiar, 2006). Sports event organizers therefore need to understand the spending behaviour of sport participants, as this has a direct bearing on the economic impact (Saayman \& Saayman, 2009). Studies of expenditure patterns help to identify the factors that influence travel expenditure characteristics (Jang et al, 2004). This is influenced by the amount spent by participating runners, the length of stay, the number of participants and the multiplier effect (Van der Merwe et al., 2007). Information about visitor expenditure patterns helps destinations to focus their marketing efforts so as to generate the maximum economic benefit in the tourism sector (Regan \& Damonte, 1999). By identifying the most appropriate target market, destinations can design their complex tourism product in a way that will best appeal to and satisfy that market. The following are some benefits of identifying the determinants of spending (Wilton \& Nickerson, 2006; Kruger, 2009; Saayman \& Saayman, 2006, 2012):

- High-yielding markets can be identified.

- Planners and marketers gain a better understanding of spending behaviour.

- Policy can be formulated on this basis.

- Resources can be allocated to specific areas to increase spending, thus influencing product development decisions.

Different tourist types or markets have different spending patterns, influenced by a wide range of socio-demographic and behavioural determinants (Craggs \& Schofield, 2006; Van der Merwe et al., 2007). Research on socio-demographic determinants shows that, in general, a higher household income has a positive effect on spending (Fish \& Waggle, 1996; Legohérel, 1998; Cannon \& Ford, 2002; Thrane, 2002; Mehmetoglu, 2007; Kruger, 2009). Distance travelled has a positive effect on spending (Long \& Perdue, 1990; Lee, 2001; Cannon \& Ford, 2002). Findings about marital status have been inconclusive (Saayman et al., 2007), though it has been found that married visitors stay fewer days and therefore spend less than their unmarried counterparts (Mak et al., 1977). Place of residence has been shown to have a positive impact on expenditure (Cannon \& Ford, 2002; Saayman \& Saayman, 2009; Kruger, 2009). Place of residence not only has a distance factor built into it, but also has to do with the disposable income of visitors from 
different regions or areas. In the case of South Africa, the richest two provinces from an income distribution point of view are Gauteng (the country's economic hub) and the Western Cape (the tourism hub) (Kruger, Saayman \& Saayman, 2010. Higher education does not necessarily mean spending more; in fact, rather the opposite has been found (Mak et al., 1977; Gokovali et al., 2007).

Contrary to general belief, travel parties that include children tend to spend less than those without children (Cai et al., 1995; Lee, 2001; Cannon \& Ford, 2002; Saayman \& Saayman, 2006). An analysis of the literature on age showed a mixture of results. Several studies found a positive relationship between age and spending (Perez \& Juaneda, 2000; Mok \& Iverson, 2000; Letho et al., 2004; Jang et al., 2004; Kastenholz, 2005; Saayman \& Saayman, 2006, Saayman \& Krugell, 2010); others found an inverse relationship (Mudami \& Baum, 1997; Pouta et al., 2006; Mehmetoglu, 2007). Findings about the effect of gender on spending have been contradictory, with studies finding either that men spend more (Thrane, 2002) or that women spend more (Letho et al., 2004; Craggs \& Schofield, 2006).

Research on determinants related to travel behaviour has shown that visitors who travelled specifically for an event spent more than those who decided to attend because they were in the vicinity (Thrane, 2002; Letho et al., 2004; Kruger, 2009; Saayman et al., 2009). This confirms the importance of travel motives. Findings about group size have been mixed: it has been found that the larger the group size, the lower the spending per person (Saayman et al., 2009), but the reverse has also been found (Lee, 2001; Seiler et al., 2002). Similarly, length of stay has been found to decrease spending per day as the number of days increases (Downward \& Lumsdon, 2002; Cannon \& Ford, 2002; Sun \& Stynes, 2006; Mehmetoglu, 2007), and to increase it (Seiler et al., 2002). The effect of repeat visitors is also inconclusive, with a positive relationship with spending being found (Gyte \& Phelps, 1989; Long \& Purdue, 1990), as well as the reverse, i.e. that first-timers spend more than repeat visitors (Oppermann, 1997; Jang et al., 2004; Petrick, 2004; Alegre \& Juaneda, 2006; Pouta et al., 2006).

From the above, it is clear that copious research has been done on the determinants of tourists' spending at events, that many variables influence spending, and that determinants differ from one attraction to the next. Of the sources cited above, only Cannon and Ford (2002) conducted their research at a sports event, in their case focusing on visitor spending and not on participants as in the present research.

\section{METHODOLOGY}

As this was quantitative research, a structured questionnaire was used to collect the data. This section describes the questionnaire, the survey and sampling method, and the statistical analysis.

\subsection{The questionnaire}

A three-section structured questionnaire, based on the works of McDonald et al. (2002), Ogles and Masters (2003) and LaChausse (2006) was used to collect the data. The same questionnaire was used in both surveys. Section A captured demographic details (gender, home language, age, occupation, home province, marital status and preferred accommodation) and spending behaviour (number of persons paid for, length of stay and expenditure), Section B captured specific information about the race (initiator of participation, frequency of participation, 
repeat participation, other tourist attractions visited and information sources regarding the event), and Section $C$ captured the motivational factors for competing in the race. In the motivation section, 24 items were measured on a five-point Likert scale: respondents were asked to indicate how important they considered each item to be on as scale where $1=$ not at all important, 2 = slightly important, 3 = important, 4 = very important and 5 = extremely important. This section also captured participants' marathon running history and how their participation in sport events influenced their choice of holiday destination and travel behaviour. Eleven statements pertaining to their travel behaviour were measured on a five-point Likert scale: $1=$ never, 2 = almost never, 3 = sometimes, 4 = regularly and 5 = always.

\subsection{Survey and sampling method}

A destination-based survey was undertaken and questionnaires were handed out on-site at the Bonitas Comrades Expo in Durban during the registration period ('up' run, 27 to 29 May 2011 and 'down' run, 29 May to 2 June 2012). Participants were selected after they had completed their registration. The field workers were trained to ensure that they understood the aim of the study and the questionnaire, and to help respondents (especially second-language English speakers) to understand the questions. Respondents were briefed about the purpose of the research beforehand to ensure that they participated willingly. In 2011 and again in 2012, a total of 450 questionnaires were distributed over a period of three days and respectively 437 and 360 completed questionnaires were included in the analysis. According to Israel (2009:6), from a population of $100,000(N), 398$ respondents $(n)$ are seen as representative and result in a $95 \%$ level of confidence. Since approximately 14900 runners took part in the race, the number of completed questionnaires is greater than the number required.

\subsection{Statistical analysis}

Microsoft Excel was used to capture the data and SPSS (2011) to analyse it.

The data from both surveys was pooled and a general profile was compiled of the participants in each race. The analysis was done in three stages: two factor analyses, calculating the dependent variable, correlation analysis and two regression analyses to identify the significant determinants of spending for the 'up' and 'down' runs of the Comrades Marathon.

First, using an Oblimin rotation with Kaiser normalization, a principal axis factor analysis was performed on each of the 21 motives and 11 travel behaviour items, to explain the variancecovariance structure of the set of variables through a few linear combinations of these variables. The Kaiser-Meyer-Olkin measure of sampling adequacy was used to determine whether the covariance matrix was suitable for factor analysis. Kaiser's criteria for the extraction of all factors with eigenvalues larger than one were used. All items with a factor loading above 0.3 were considered as contributing to a factor, whereas those with loadings lower than 0.3 were considered as not correlating significantly with this factor (Steyn, 2000; Pallant, 2005). In addition, any item that cross-loaded on two factors, with factor loadings greater than 0.3 , was categorized in the factor where interpretability was best. A reliability coefficient (Cronbach's alpha) was computed to estimate the internal consistency of each factor. All factors with a reliability coefficient above 0.6 were considered as acceptable in this study. The average inter-item correlations were also computed as another measure of reliability, which should lie between 0.15 and 0.55 (Clark \& Watson, 1995). 
Second, the dependent (predicted) variable, spending per participant, was calculated by summing the participant's spending on the various components asked. This gave total spending, which was then divided by the number of people for whom the participant was paying on the trip, to give spending per participant. The dummy variables (socio-demographic and behavioural) were coded $l$ and 0 to be included in the correlation and regression analyses.

Third, correlation analysis and Spearman's rank order correlation (rho) were used to explore the interrelationship between the independent (i.e. dummy) variables and the dependent variable (spending per participant). According to Pallant (2010:134), a correlation of 0 indicates no relationship, a correlation of 1.0 indicates a perfect positive correlation, and a value of -1.0 indicates a perfect negative correlation. Cohen (1988:79-81) suggests the following guidelines to interpret the values between 0 and 1 : small effect $r=0.1$, medium effect $r=0.3$, and large effect $r=0.5$.

Fourth, based on the results of the correlation analysis, the best predictors for the dependent variable for each of the two races were selected and linear stepwise regression analysis was performed to identify the determinants of participant spending at each race. In the regression analysis, $R^{2}$ gives the proportion of variance in spending that is explained by the predictors included in the model. An $R^{2}$ of 0.25 or larger can be considered as practically significant ( $\varepsilon$ llis \& Steyn, 2003:53). The adjusted $R^{2}$ indicates how much variance in the outcome would be accounted for if the model had been derived from the population from which the sample was taken and also takes into account the number of explanatory variables in the model (Field, 2005:723). The adjusted $R^{2}$ therefore gives an idea of how well the regression model generalizes and, ideally, its value needs to be the same or very close to the value of $R^{2}$ (Field, 2005:188). The results from the statistical analyses are discussed in the next section.

\section{RESULTS}

This section describes the profile of the respondents (participants at the Comrades Marathon), discusses the results of the factor analysis (travel motives and travel behaviour) and the correlation analysis, and presents the results of the linear stepwise regression analysis.

\subsection{Profile of respondents}

TABLE 1 shows that participants in the two Comrades races, the 'up' run and the 'down' run, had similar demographic profiles. Respectively, they were on average 43 and 40 years old, predominantly male (77\% and $76 \%$ ), married (66\% and $60 \%$ ), English-speaking ( $48 \%$ and $57 \%$ ) and from the Gauteng Province (35\% and $32 \%$ ). On average, participants travelled to the race in groups of five, were financially responsible for two people during the event and stayed four nights in the Pietermaritzburg or Durban area. The only differences between the respondents were the number of times they had taken part in the race (in either direction) and the amount they spent. 'Up' runners had participated more often (an average of six times) than the 'down' runners (an average of five times). 'Up' runners spent on average significantly more than the 'down' runners (R7 173 as compared to R5 379). It is however important to note that the surveys were done a year apart and inflation and price increases may have had an influence on participants' spending. As accommodation usually makes up a large portion of spending, the average price for accommodation may also differ in the two locations, which can have significant influences on spending, especially taking into consideration that in the case of both 
races participants stayed an average of four nights in the area. However, it would be premature to ascribe the difference in spending to these reasons at this stage, on the basis of just two surveys.

TABLE 1: Profile of the 'up' and 'down' Comrades Marathon participant

\begin{tabular}{lll}
\hline Characteristics & 'Up'run & 'Down' run \\
\hline Gender & Male (77\%); Female (23\%) & Male (76\%); Female (24\%) \\
\hline Average age & 43 years & 40 years \\
\hline Marital status & Married (66\%); Not married & Married (60\%); Not married \\
$(22 \%)$ & $(40 \%)$
\end{tabular}

Source: Authors' compilation

\subsection{Results from the factor analysis: Motives for competing}

The pattern matrix of the principal axis factor analysis using an Oblimin rotation with Kaiser normalization identified three motivation factors for competing in the Comrades Marathon and two holiday destination choice factors. These factors were labelled according to similar characteristics (see Tables 2 and 3 ) and accounted for $57 \%$ of the total variance. All the factors had relatively high reliability coefficients, ranging from 0.79 (the lowest) to 0.84 (the highest) for the motivational factors and 0.65 (the lowest) to 0.88 (the highest) for the holiday destination choice factors. The average inter-item correlation coefficients with values between 0.39 and 0.66 for the motivational factors and 0.38 and 0.48 for the holiday destination choice factors also implied internal consistency for all factors. Moreover, all items loaded on a factor with a loading greater than 0.3 , and the relatively high factor loadings indicated a reasonably high correlation between the factors and their component items. The Kaiser-Meyer-Olkin measures of sampling adequacy of 0.88 for the motivational factors and 0.91 for the holiday destination choice factors also indicated that patterns of correlation were relatively compact and yielded distinct and reliable factors (Field, 2005:640). Barlett's test of sphericity also reached statistical significance $(p<.001)$, supporting the factorability of the correlation matrix (Pallant, 2007). 
TABLE 2: Results of factor analysis of motives for participating in the Comrades Marathon ('up' and 'down' runs)

\begin{tabular}{|c|c|c|c|}
\hline Motivational factors and items & 1 & 2 & 3 \\
\hline \multicolumn{4}{|l|}{ Factor 1: Intrinsic achievement and challenge } \\
\hline To feel proud of myself and to feel a sense of achievement & 0.80 & & \\
\hline Comrades is a major challenge & 0.78 & & \\
\hline Because I enjoy running & 0.65 & & \\
\hline Because the event is well-organized & 0.59 & & \\
\hline It is a 'must-do' event & 0.54 & & \\
\hline Comrades tests my level of fitness and endurance & 0.52 & & \\
\hline To improve my health & 0.45 & & \\
\hline It is an international event & 0.36 & & \\
\hline \multicolumn{4}{|l|}{ Factor 2: Socialization and group identity } \\
\hline To meet new people & & 0.77 & \\
\hline To socialize with other runners & & 0.69 & \\
\hline To share group identity with other runners & & 0.64 & \\
\hline $\begin{array}{l}\text { I am pursuing a personal goal of participating in a certain number of } \\
\text { marathons }\end{array}$ & & 0.47 & \\
\hline To spend time with family and friends & & 0.45 & \\
\hline I do it annually & & 0.34 & \\
\hline \multicolumn{4}{|l|}{ Factor 3: Escape } \\
\hline To relax & & & 0.80 \\
\hline To get away from my normal routine and stress & & & 0.63 \\
\hline Total variance explained & $57 \%$ & & \\
\hline Reliability coefficient & 0.84 & 0.79 & 0.79 \\
\hline Average inter-item correlation & 0.40 & 0.39 & 0.66 \\
\hline Mean value & 3.97 & 3.28 & 3.32 \\
\hline
\end{tabular}

Source: Authors' compilation

Factor scores were calculated as the average of all items contributing to a specific factor in order to interpret them on the original five-point Likert scale. As TABLE 2 shows, Intrinsic achievement and challenge (Factor 1 ) obtained the highest mean value (3.97) and was the main reason mentioned for competing in the Comrades, followed by Escape (Factor 3) (3.32) and Socialization and group identity (Factor 2) (3.28). 
Kruger \& Saayman

TABLE 3: Results of factor analysis of the influence of sport participation on holiday destination choice and travel behaviour

\begin{tabular}{|c|c|c|c|c|}
\hline $\begin{array}{l}\text { Holiday destination choice and travel } \\
\text { behaviour items }\end{array}$ & $\begin{array}{l}\text { Factor } \\
\text { loading }\end{array}$ & $\begin{array}{l}\text { Mean } \\
\text { value }\end{array}$ & $\begin{array}{l}\text { Reliability } \\
\text { coefficient }\end{array}$ & $\begin{array}{l}\text { Average } \\
\text { inter-item } \\
\text { correlation }\end{array}$ \\
\hline Factor 1: Primary influences & & 3.31 & 0.88 & 0.48 \\
\hline $\begin{array}{l}\text { My sport participation gives me the } \\
\text { opportunity to explore the country }\end{array}$ & 0.88 & & & \\
\hline $\begin{array}{l}\text { I plan my sport participation in order to see } \\
\text { different places and destinations }\end{array}$ & 0.86 & & & \\
\hline $\begin{array}{l}\text { I also take a holiday during my } \\
\text { participation in running events }\end{array}$ & 0.77 & & & \\
\hline $\begin{array}{l}\text { Participation in sport gives me the } \\
\text { opportunity to travel }\end{array}$ & 0.71 & & & \\
\hline $\begin{array}{l}\text { Participation in sport allows me to take my } \\
\text { family and friends along on the trip }\end{array}$ & 0.61 & & & \\
\hline $\begin{array}{l}\text { I take a holiday in the town or area where I } \\
\text { have participated }\end{array}$ & 0.56 & & & \\
\hline $\begin{array}{l}\text { My sport participation gives me the } \\
\text { opportunity to travel overseas }\end{array}$ & 0.54 & & & \\
\hline $\begin{array}{l}\text { My holiday destination needs to give me the } \\
\text { opportunity to train }\end{array}$ & 0.49 & & & \\
\hline Factor 2: Secondary influences & & 3.07 & 0.65 & 0.38 \\
\hline $\begin{array}{l}\text { My sport participation and holiday } \\
\text { destination differ }\end{array}$ & 0.67 & & & \\
\hline $\begin{array}{l}\text { I prefer to go on holiday at a different } \\
\text { destination than where I have participated } \\
\text { - at least once a year }\end{array}$ & 0.64 & & & \\
\hline $\begin{array}{l}\text { I prefer not to spend a lot of time at the } \\
\text { destination where I participate in a } \\
\text { particularsport }\end{array}$ & 0.49 & & & \\
\hline Total variance explained & $57 \%$ & & & \\
\hline
\end{tabular}

Source: Authors' compilation

With regard to the influence of participation in sport on participants' holiday destination choice and travel behaviour (TABLE 3), two factors were identified: Primary influences (Factor 1 ) and Secondary influences (Factor 2). Primary influences obtained the higher mean value (3.31) of the two factors, indicating that participants said their participation in sport sometimes influenced their holiday destination choice and travel behaviour. However, the mean value of Secondary influences (3.07) indicated that participants also preferred to take a holiday at a destination other than where they had to participate. 


\subsection{Results from the correlation analysis and Spearman's tho}

Most questions had multiple choice responses or were answered on a five-point Likert scale and the dummy variables were coded 1 and 0 as shown in TABL $\varepsilon 4$. These variables were included in the correlation analyses to determine the variables that had the greatest influence on spending per participant at the 'up' and 'down' runs of the Comrades Marathon. The relationship between the variables shown in TABLE 4 and spending per participant was investigated using Spearman's rank order correlation (rho).

TABLE 4: Categories of questions asked for the 'up' and 'down' runs of the Comrades Marathon

\begin{tabular}{|c|c|c|c|}
\hline Category & Question description & Coding & Variable \\
\hline \multirow{6}{*}{$\begin{array}{l}\text { Socio- } \\
\text { demographics }\end{array}$} & Home language & English $=1 ;$ Other $=0$ & LANGUAGE \\
\hline & Gender & Male $=1 ;$ Female $=0$ & GENDER \\
\hline & Age & Open question & $A G E$ \\
\hline & Province of origin & $\begin{array}{l}\text { KwaZulu-Natal = } 1 ; \\
\text { Other = } \\
\text { Gauteng = } 1 ; \text { Other = - }\end{array}$ & $\begin{array}{l}\text { KWAZULU-NATAL } \\
\text { GAUTENG }\end{array}$ \\
\hline & Level of education* & High level $=1 ;$ Other $=0$ & LEVEL OF EDUCATION \\
\hline & Marital status & $\begin{array}{l}\text { Married }=1 ; \\
\text { Not married }=0\end{array}$ & MARITAL STATUS \\
\hline \multirow[t]{6}{*}{ Behavioural } & Group size & Open question & GROUP \\
\hline & Number of people paid for & Open question & PEOPLE PAID FOR \\
\hline & Number of nights & Open question & NIGHTS \\
\hline & $\begin{array}{l}\text { Number of previous } \\
\text { participation }\end{array}$ & Open question & TIMES PARTICIPATED \\
\hline & $\begin{array}{l}\text { Number of marathons per } \\
\text { year }\end{array}$ & Open question & MARATHONS PER YEAR \\
\hline & Tourist attractions visited & $y_{e s}=1 ;$ No $=0$ & TOURIST ATTRACTIONS \\
\hline \multirow{7}{*}{$\begin{array}{l}\text { Initiated } \\
\text { participation }\end{array}$} & Self & $y_{e s}=1 ; N_{0}=0$ & SELF \\
\hline & Spouse & $y_{e s}=1 ; N_{0}=0$ & SPOUSE \\
\hline & Media & $y_{e s}=1 ; N_{0}=0$ & MEDIA \\
\hline & Friends & $y_{e s}=1 ; N_{0}=0$ & FRIENDS \\
\hline & Children & $y_{e s}=1 ; N_{0}=0$ & CHILDREN \\
\hline & Family & $y_{e s}=1 ; N_{0}=0$ & FAMILY \\
\hline & Club & Yes $=1 ;$ No = 0 & CLUB \\
\hline \multirow{2}{*}{$\begin{array}{l}\text { Media } \\
\text { preferences }\end{array}$} & Television & $y_{e s}=1 ; N_{o}=0$ & TV \\
\hline & Radio & Yes $=1 ;$ No $=0$ & RADIO \\
\hline
\end{tabular}




\begin{tabular}{|c|c|c|c|}
\hline & Website & Yes $=1 ;$ No $=0$ & WEBSITE \\
\hline & Magazines & Yes $=1 ;$ No $=0$ & MAGAZINES \\
\hline & Newspapers & Yes $=1 ;$ No $=0$ & NEWSPAPERS \\
\hline & Word-of-mouth & Yes $=1 ;$ No $=0$ & WORD-OF-MOUTH \\
\hline & Club & Yes $=1 ; N_{0}=0$ & CLUB \\
\hline \multirow[t]{3}{*}{$\begin{array}{l}\text { Motives for } \\
\text { participating }\end{array}$} & $\begin{array}{l}\text { Intrinsic achievement and } \\
\text { challenge }\end{array}$ & 5 -point Likert scale & $\begin{array}{l}\text { INTRINSIC ACHIEVEMENT } \\
\text { AND CHALLENGE }\end{array}$ \\
\hline & $\begin{array}{l}\text { Socialization and group } \\
\text { identity }\end{array}$ & 5-point Likert scale & $\begin{array}{l}\text { SOCIALIZATION AND } \\
\text { GROUP IDENTITY }\end{array}$ \\
\hline & Escape & 5-point Likert scale & ESCAPE \\
\hline \multirow{2}{*}{$\begin{array}{l}\text { Holiday } \\
\text { destination } \\
\text { choice } \\
\text { behaviour }\end{array}$} & Primary influences & 5-point Likert scale & PRIMARY INFLUENCES \\
\hline & Secondary influences & 5-point Likert scale & SECONDARY INFLUENCES \\
\hline
\end{tabular}

Source: Authors' compilation

* High level= Diploma, degree, Postgraduate, Professional; Other = No school, Matric

The following variables had a small relationship with spending per participant at the 'down' run:

- There was a small, negative correlation between language ( $r h o=-.10, \mathrm{n}=293, p=.075$ ) and people paid for ( $r$ o $=-.20, \mathrm{n}=283, p=.001$ ), indicating that $\varepsilon$ nglish-speaking participants and participants who were financially responsible for more people at the race tended to be lower spenders.

- KwaZulu-Natal (rho $=-.13, \mathrm{n}=283, p=.033$ ) and times participated (rho $=.10, \mathrm{n}=265, p=$ .179) had respectively a small, negative and a small, positive correlation with spending per participant, indicating that participants originating from the host province tended to be lower spenders at the race, while those who had participated more times in the Comrades tended to be higher spenders.

- Television ( $r h o=.12, n=265, p=.049$ ) had a small, positive correlation with spending per participant, indicating that participants who had heard about the race from this marketing medium tended to be higher spenders.

- Tourist attractions ( $r h o=-.19, \mathrm{n}=260, p=.003$ ) and marathons per year ( $r$ ho $=-.10, \mathrm{n}=212$, $p=.236$ ) had small, negative correlations with spending per participant, indicating that participants who visited other tourist attractions and who participated in more marathons per year tended to be lower spenders.

The following variables had some degree of correlation with spending per participant at the 'up' run:

- People paid for (rho $=-.38, \mathrm{n}=386, p=.001$ ) and KwaZulu-Natal (rho $=-.30, \mathrm{n}=386, p=$ .001 ) had medium, negative correlations with spending per participant, indicating that participants who were financially responsible for more people at the race and who originated from the host province, KwaZulu-Natal, tended to be lower spenders. 
- Nights ( $r h o=.16, \mathrm{n}=330, p=.003$ ) had a small, positive correlation with spending per participant, indicating that participants who spent more nights in the area tended to be higher spenders.

- Level of education ( $r h o=.21, \mathrm{n}=386, p=.001$ ) had a small, positive correlation with spending per participant, indicating that participants with a high level of education tended to be higher spenders.

- Times participated ( $r h o=-.11, \mathrm{n}=353, p=.041$ ) and marital status (rho $=-.10, \mathrm{n}=386, p=$ .071 ) had small, negative correlations with spending per participant, indicating that married participants who had participated more times in the Comrades tended to be lower spenders.

- The marketing media, website ( $r$ ho $=.10, \mathrm{n}=386, p=.070$ ), magazine ( $r$ o $=.10, \mathrm{n}=386, p=$ .127 ), newspapers (rho $=.10, \mathrm{n}=386, p=.078$ ) and word-of-mouth (rho $=.17, \mathrm{n}=386, p=$ .001 ) had small, positive correlations with spending per participant, indicating that participants who had heard about the race from these media tended to be higher spenders.

- Participants who had been persuaded to participate in the race by their children (rho = $.13, \mathrm{n}=386, p=.014$ ), who visited other tourist attractions during the event (rho $=-.11$, $\mathrm{n}=386, p=.027$ ) and who were motivated by Socialization and group identity (rho $=-.10$, $\mathrm{n}=336, p=.158)$ tended to be lower spenders.

- Participants whose holiday destination choice was influenced by their sport participation (primary influences, rho $=.12, \mathrm{n}=337, p=.027$ ) tended to be higher spenders at the race.

\subsection{Results of the backward linear regression analyses}

Backward linear regression was performed to assess the impact of a number of factors on the likelihood that the per participant spending in the 'up' and 'down' runs would increase. The model contained the independent variables dummy coded as 1 and 0 in TABLE 4 that correlated most strongly with spending per participant. The significant variables for the participants explained respectively $13 \%$ ('down' run) and $14 \%$ ('up' run) of the total variance. The results are discussed below.

\subsection{Determinants of participant spending: 'Down' run}

In the case of the participants competing in the 'down' run, tourist attractions, TABLE 5 shows that people paid for and KwaZulu-Natal province were the only significant variables, $F(3,167)=$ $8.341, p<.001$. The negative signs indicate that participants who visited tourist attractions (beta $=-.252, p=.001$ ), who were financially responsible for more people at the race (beta= $.160, p=.041$ ) and who originated from KwaZulu-Natal (beta=-.197, $p=.011$ ) tended to be lower spenders at the race. 
TABLE 5: Results from the backward linear regression: determinants of participant spending for the 'down' run

\begin{tabular}{lcccccc}
\hline & \multicolumn{2}{c}{ Unstandardized } & Standardized & & \\
& \multicolumn{2}{c}{ coefficients } & coefficients & $t$ & Sig. \\
& B & Std. error & Beta & & \\
\hline (Constant) & 7363.395 & 1035.941 & & 7.108 & $.000^{*}$ \\
\hline TOURIST ATTRACTIONS & -664.161 & 192.472 & -.252 & -3.451 & $.001^{\star}$ \\
PEOPLE PAID FOR & -1851.825 & 897.503 & -.160 & -2.063 & $.041^{\star}$ \\
KWAZULU-NATAL & -1721.957 & 672.341 & -.197 & -2.561 & $.011^{*}$ \\
\hline
\end{tabular}

Source: Authors' compilation

* Statistically significant difference: $p \leq .05$

\subsection{Determinants of participant spending: 'Up' run}

In the case of the participants competing in the 'up' run, TABLE 6 shows that people paid for, nights, marital status and the travel motive Socialization and group affiliation were the only significant variables, $f(4,269)=11.099, p<.001$. The negative signs of the coefficients indicate that participants who were financially responsible for more people at the race (beta $=-.196, p=$ .001 ), who were married (beta $=-.182, p=.001$ ) and who were motivated by Socialization and group identity (beta $=-133, p=.020$ ) tended to be lower spenders at the race. The positive sign of the coefficient in the nights category (beta $=.236, p=.001$ ) indicates that participants who spent more nights in the area spent more at the race, which was to be expected.

TABLE 6: Results from the backward linear regression: determinants of participant spending for the 'up' run

\begin{tabular}{lccccc}
\hline & \multicolumn{2}{c}{ Unstandardized } & Standardized & & \\
& coefficients & coefficients & $t$ & Sig. \\
& $B$ & Std. error & Beta & & \\
\hline (Constant) & 10084.418 & 2148.142 & & 4.694 & $.000^{\star}$ \\
\hline PEOPLE PAID FOR & -707.177 & 203.785 & -.196 & -3.470 & $.001^{\star}$ \\
\hline NIGHTS & 832.123 & 199.161 & .236 & 4.178 & $.000^{\star}$ \\
MARITAL STATUS & -3425.298 & 1067.536 & -.182 & -3.209 & $.001^{\star}$ \\
\hline $\begin{array}{l}\text { SOCIALIZATION AND } \\
\text { GROUP IDENTITY }\end{array}$ & -1263.021 & 538.065 & -.133 & -2.347 & .020 * \\
\hline
\end{tabular}

Source: Authors' compilation

* Statistically significant difference: $p \leq .05$ 


\section{FINDINGS AND IMPLICATIONS}

The purpose of this study was to establish the determinants of spending by ultra-marathon runners at the 'up' and 'down' runs of the Comrades Marathon, and specifically to answer the four questions raised in the introduction. The statistical analysis revealed significant differences between the distribution of spending and the spending behaviour of participants at the event in 2011 and 2012, with different determinants being at play in each case. The results thereby corroborate the finding by Craggs and Schofield (2006) that a variety of sociodemographic and behavioural determinants influence visitor spending. More behavioural determinants (people paid for, nights spent, motive for competing, tourist attractions visited) than socio-demographic determinants (marital status, province of origin) had a significant influence on spending at both races. The results furthermore corroborate the finding by Saayman and Saayman (2011) and Kruger et al. (2012) that different factors may be applicable or significant for different sport participants and therefore event organizers should not treat all endurance sport participants the same, if the intention is to increase visitor spending. The results also show that the organizers' approach should differ for participants competing in the same event, and from one event to the next.

At the 'down' run, the lower spenders were typically English-speaking runners from KwaZuluNatal and financially responsible for more people than the 'up' runners were. These results are consistent with the finding by Saayman et al. (2009) that, because they share costs, people who travel in larger groups tends to spend less. Interestingly, those who had taken part in previous Comrades Marathons were the bigger spenders. The reasons for this are, however, not clear. In terms of place of residence, the results contradicted the finding by Cannon and Ford (2002), Saayman and Saayman (2009) and Kruger (2009) that place of residence has a positive effect on expenditure. This could be because local residents from KwaZulu-Natal who participate in the Comrades do not have additional travel or accommodation expenses. Corresponding with the research by Gyte and Phelps (1989) and Long and Perdue (1990), repeat participants spent more than first-time participants. Surprisingly, those who did not visit other tourist attractions, perhaps because they were focused and serious competitors and did not have the time or inclination for such visits, spent more than those who did visit other attractions. The influence of visiting tourist attractions has not previously been found in the literature.

At the 'up' run, the motive Socialization and group identity was significant, but had a negative influence on higher spending. While not important for spending, this motive does, however, capture the spirit of this ultra-marathon. Although the participants run as individuals, they value socialization during the event, with spectators supporting runners, and runners supporting each other. Since camaraderie plays an important part, it can therefore also be used in marketing campaigns.

As in the case of the 'down' run, in the 'up' run the lower spenders were those from KwaZuluNatal, those who were responsible for more people financially and those who visited other attractions. The higher spenders were those who stayed longer, were well-educated and whose choice of holiday destination was influenced by their sport participation. These findings support the finding by Downward and Lumsdon (2002), Cannon and Ford (2002), Sun and Stynes (2006) and Mehmetoglu (2007) that a longer stay is positively associated with higher expenditure levels, but contradict the finding by Mak et al. (1977) and Gokovali et al. (2007) that visitors with a higher level of education tended to be lower spenders. 
The findings of this research have the following implications. First, ultra-marathon event organizers specifically, and sport event managers and planners generally, need to take cognizance of this research, especially since the differences in spending were found to be influenced by different variables. The findings could show organizers how to focus their marketing strategy and campaign so as to increase the economic impact of endurance events, and particularly those that have alternating routes.

Second, participants who spend more nights in the area tend to spend more, and although this is to be expected it still has to be managed. For example, event organizers could consider introducing special packages offering the runners discounts for restaurants, transport and accommodation. This could also attract more participants from surrounding provinces, as they are the bigger spenders.

Third, the results showed that those runners who participate more frequently and in a variety of marathons are the bigger spenders. Event organizers should therefore market this marathon at similar events and at various running clubs. Emphasis should be placed on the special features that distinguish the two races, the 'up' and the 'down' run. Incentives for participating could also be used to attract frequent runners. Participants should furthermore be made more aware of the 'green number club' for runners who have participated 10 or more times in the Comrades.

\section{CONCLUSION}

This was the first time that the determinants of spending have been identified at an ultramarathon that is run in alternating directions annually, predominantly uphill one year and predominantly downhill the next year. Therefore the results are important not only for sport and economic tourism literature but also for practitioners, especially event organizers and managers. The results confirm that events differ, and that variations of a single event differ too. It is also the first study where variables concerning athletes' tourist behaviour before the event have been used in statistical analysis in research into determinants of spending. An interesting finding was that even though the two groups of participants had very similar profiles, their spending at the event differed significantly, being distributed differently, and with the spend being higher at the 'up' run. This difference could be ascribed to the fact that accommodation and related expenses may be more expensive in Durban; however, this aspect needs further investigation. The 'up' and the 'down' runs may therefore have different economic outcomes, though this cannot be confirmed on the basis of surveys of just two years. In addition, it was found that different variables influenced participant spending at the two events. There was also a greater variety of determinants for the more difficult 'up' run than for the 'down' run. It is recommended that similar research be conducted at other events that have varying forms, to allow for comparison of results.

\section{Acknowledgement}

The authors gratefully acknowledge financial assistance from the National Research Foundation (NRF). We are also grateful to the organisers of the Comrades Marathon for allowing the research to be conducted as well as to all the fieldworkers and respondents. 


\section{LIST OF REFERENCES}

Alegre, J. \& Juaneda, C. (2006). Destination loyalty: consumers' economic behaviour. Annals of Tourism Research, 33(3), pp. 684-706.

Bodet, G. \& Bernache-Assollant, I. (2009). Do fans care for hot dogs? A satisfaction analysis of French ice hockey spectators. International Journal of Sport Management and Marketing, 5(1), pp. $15-37$.

Boen, F., Vanbeselaere, N. \& Swinnen, H. (2005). Predicting fan support in a merger between soccer teams: A social psychological perspective. International Journal of Sport Psychology, 36(1), pp. 1-21.

Boen, F., Vanbeselaere, N., Pandelaere, M., Shutters, K. \& Rowe, P. (2008). When your team is not really your team anymore: identification with a merged basketball club. Journal of Applied Sport Psychology, 20(2), pp. 165-183.

Bureau of Economic Analysis (BEA). (2000). Selected personal consumption in the US, 1991-1997. Washington: US Government Printing Office.

Burfoot, A. (2007). The history of the marathon. Sports Medicine, 37(4-5), pp. 284-287.

Cai, L.A., Hong, G. \& Morrison, A.M. (1995). Household expenditure patterns for tourism products and services. Journal of Travel and Tourism Marketing, 4(4), pp. 15-40.

Cannon, T.F. \& Ford, J. (2002). Relationship of demographic and trip characteristics to visitor spending: an analysis of sport travel visitors across time. Tourism Economics, 8(3), pp. 263-271.

Clark, L.A. \& Watson, D. (1995). Constructing validity: basic issues in objective scale development. Psychological Assessment, 7(3), pp. 309-319.

Cohen, J. (1988). Statistical power analysis for the behavioral sciences, $2^{\text {nd }}$ edition. Hillsdale: Erlbaum.

Craggs, R. \& Schofield, P. (2006). Expenditure segmentation and visitor profiling: regenerating the Quays in Salford, UK. University of Northumberland, University of Salford.

Crosset, T. (1995). Toward an understanding of on-site fan-athlete relations: a case study of the LPGA. Sport Marketing Quarterly, 4(2), pp. 31-38.

Downward, P.M. \& Lumdson, L. (2001). The development of recreational cycle routes: an evaluation of user needs. Managing Leisure, 6(1), pp. 50-60.

Ellis, S.M. \& Steyn, H.S. (2003). Practical significance (effect sizes) versus or in combination with statistical significance (p values). Management dynamics, 12(1), pp. 51-53.

Field, A. (2005), Discovering Statistics Using SPSS, $2^{\text {nd }}$ edition. London: SAGE.

Fish, M. \& Waggle, D. (1996). Current income versus total expenditure measure in regression models of vocational and pleasure travel. Journal of Travel Research, 35(2), pp. 70-74.

Giulianotti, R. (2002). Supporters, followers, fans and flâneurs: a taxonomy of spectator identities in football. Journal of Sport and Social Issues, 26(1), pp. 25-46.

Gokovali, U., Bahar, 0.\& Kozak, M. (2007). Determinants of length of stay: A practical use of survival analysis. Tourism Management, 28(3), pp.736-746.

Gyte, D.M. \& Phelps, A. (1989). Patterns of destination repeat business: British tourists in Mallorca, Spain. Journal of Travel Research, 28(1), pp. 24-28. 
Hill, B. \& Green, B.C. (2000). Repeat attendance as a function of loyalty and the sportscape across three football contexts. Sport Management Review, 3(2), pp. 145-162.

Israel, G.D. (2009). Determining sample size. Available: www.edis.ifas.ufl.edu/pdffiles/pd/pd00600.pdf. (Accessed 12 May 2010).

Jang, S., Bai, B., Hong, G. \& O'Leary, J.T. (2004). Understanding travel expenditure patterns: A study of Japanese pleasure travelers to the United States by income level. Tourism Management, 25(3), pp. 331-341.

Kastenholz, દ. (2005). Analysing determinants of visitor spending for the rural tourist market in North Portugal. Tourism Economics, 11(4), pp. 555-569.

Kruger, M. (2009). Spending behaviour of visitors to the Klein Karoo National Arts Festival. Unpublished PhD thesis. Potchefstroom: North-West University.

Kruger, M., Saayman, M. \& Ellis, S.M. (2012). Determinants of visitor spending at the Two Oceans Marathon. Tourism Economics, 18(6), pp. 1203-1227.

Lachausse, R.G. (2006). Motives of competitive and non-competitive cyclists. Journal of Sport Behavior, 29(4), pp. 304-314.

Lee, H.C. (2001). Determinants of recreational boater expenditure on trips. Tourism Management, 22(6), pp. 659-667.

Legohérel, P. (1998). Toward a market segmentation of the Tourism Trade: Expenditure levels and consumer behaviour instability. Journal of Travel and Tourism Marketing, 7(3), pp. 19-39.

Letho, X.Y., Cai, L.A., O'Leary, J.T. \& Huan, T.C. (2004). Tourists' shopping preferences and expenditure behaviours: the case of the Taiwanese outbound market. Journal of Vacation Marketing, 10(4), pp. $320-332$.

Long, P.T. \& Perdue, R.R. (1990). The economic impact of rural festivals and special events: Assessing the spatial distribution of expenditures. Journal of Travel Research, 39(4), pp. 10-14.

Mak, J. (2004). Tourism and the economy: Understanding the economics of tourism. Honolulu: University of Hawaii Press.

Mak, J., Moncur, J. \& Yonamine, D. (1977). Who or how not to measure visitor expenditures. Journal of Travel Research, 16(1), pp. 1-4.

McDonald, M.A., Milne, R.G. \& Hong, J. (2002). Motivational factors for evaluating sport spectator and participant markets. Sport marketing quarterly, 11(2), pp. 100-113.

Mehmetoglu, M. (2007). Nature-based tourists: the relationship between their trip expenditures and activities. Journal of Sustainable Tourism, 15(2), pp. 200-215.

Mok, C. \& Iverson, T.J. (2000). Expenditure-based segmentation: Taiwanese tourists to Guam. Tourism Management, 21(3), pp. 299-305.

Mottiar, Z. (2006). Holiday home owners, a route to sustainable tourism development? An economic analysis of tourist expenditure. Journal of Sustainable Tourism, 14(6), pp. 582-599.

Mudambi, R. \& Baum, T. (1997). Strategic segmentation: an empirical analysis of tourist expenditure in Turkey. Journal of Travel Research, 36(1), pp. 29-34.

Narayan, P.K. (2003). Determinants of tourist expenditure in Fiji: co-integration approach. Pacific Tourism Review, 6(3/4), pp. 159-167. 
Ogles, B.J. \& Masters, K.S. (2003). A typology of marathon runners based on cluster analysis of motivations. Journal of Sport Behaviour, 26(1), pp. 69-85.

Oppermann, M. (1997). First time and repeat tourists to New Zealand. Tourism Management, 18(3), pp. 171-181.

Pallant, J. (2010). SPSS Survival manual: a step-by-step guide to data analysis using SPSS version 16, $4^{\text {th }}$ edition. New York: McGraw-Hill.

Pan, D.W., Gabert, T.E., McGaugh, E.C. \& Branvoid, S.E. (1997). Factors contributing to the purchase of season tickets for intercollegiate basketball games. Journal of Sport Behavior, 20(1), pp. 447-464.

Perez, E.A. \& Juaneda, S.C. (2000). Tourism expenditure for mass tourism markets. Annals of Tourism Research, 27(3), pp. 627-637.

Petrick, J.F. (2004). First timers' and repeaters' perceived value'. Journal of Travel Research, 43(1), pp. 29-38.

Pouta, દ., Neuvonen, M. \& Sievanen, T. (2006). Determinants of Nature trip expenditure in Southern Finland - Implications for nature tourism development. Scandinavian Journal of Hospitality and Tourism, 6(2), pp. 118-135.

Pucher, U. \& Buehler, R. (2007). At the frontiers of cycling: Policy innovations in the Netherlands, Denmark and Germany. World Transport Policy \& Practice, 13(3), pp. 2-73.

Regan, T.H. \& Damonte, T. (1999). A geo-economic approach to South Carolina NASCAR markets. Public Administration Quarterly, 23(3), pp. 295-312.

Robinson, M.J., Trail, G.T. \& Kwon, H. (2004). Motives and points of attachment of professional golf spectators. Sport Management Review, 7(2), pp. 187-192.

Saayman, A. \& Saayman, M. (2006). Socio-demographics and visiting patterns of arts festivals in South Africa. Event Management, 9(4), pp. 211-222.

Saayman, A. \& Saayman, M. (2009). Socio-demographic and behavioural determinants of visitor spending at the Kruger National Park in South Africa. South African Journal of Economics and Management Sciences, 12(4), pp. 493-512.

Saayman, M. \& Saayman, A. (2012). Determinants of spending: an evaluation of three major sporting events'. International Journal of Tourism Research, 14(2), pp. 124-138.

Saayman, M. \& Saayman, A. (2012). The economic impact of the Comrades Marathon. International Journal of Event and Festival Management, 3(3), pp. 220-235.

Saayman, M., Rossouw, R. \& Saayman, A. (2008). Economic impact of visitor spending at the Cape Argus Cycle Tour. Africa Insight, 38(3), pp. 100-122.

Saayman, M., Saayman, A. \& Streicher, H. (2008). Motives of cyclists participating in the Pick $n$ Pay Cape Argus Cycle Tour. Unpublished research report. Potchefstroom: Institute for Tourism and Leisure Studies.

Saayman, M., Saayman, A., Slabbert, દ. \& Viviers, P. (2007). Die sosio-ekonomiese impak van besoekers na KKNK. Unpublished research report. Potchefstroom: Institute for Tourism and Leisure Studies.

Saayman, M., Van der Merwe, P. \& Pienaar, J. (2009). Expenditure based segmentation of tourists to Kruger National Park. Acta Academica, 41(3), pp. 107-127. 
Seiler, V.L., Hsieh, S., Seiler, M.J. \& Hsieh, C. (2002). Modeling travel expenditures for Taiwanese tourism. Journal of Travel and Tourism Marketing, 13(4), pp. 47-59.

SPSS (Statistical Package for the Social Sciences). (2011). SPSS ${ }^{17.0}$ for Windows, Release 16.0.0, Copyright $\odot$ by SPSS inc., Chicago, Illinois.

Steyn, H.S. (2000). Practical significance of the difference in means. South African Journal of Industrial Psychology, 26(3), pp. 1-3.

Sun, Y. \& Stynes. D.J. (2006). A note on estimating visitor spending on a per-day/night basis. Tourism Management, 27(4), pp. 721-725.

Tapp, A. \& Clowes, J. (2002). From "care-free casuals" to "professional wanderers": segmentation possibilities for football supporters. European Journal of Marketing, 36(11/12), pp. 1248-1269.

Thrane, C. (2002). Jazz festival visitors and their expenditures: linking spending patterns to musical interest. Journal of Travel Research, 40(3), pp. 281-286.

Trail, G.T., Robinson, M.J., Dick, R.J. \& Gillentine, A.J. (2003). Motives and points of attachment: Fans versus spectators in intercollegiate athletics. Sport Marketing Quarterly, 12(4), pp. 217-227.

Travel Industry Association of America (TIA). (1996). Profile of travelers who attend sports events. Washington: TIA.

Van Der Merwe, P., Saayman, M. \& Krugell, W. (2007), The determinants of spending by biltong hunters. South African Journal of Economic and Management Sciences, 10(2), pp. 184-194.

Weed, M. (2006). Editorial: Introducing the Journal of Sport and Tourism. Journal of Sport and Tourism, 11(1), pp. 1-4.

Wilton, J.J. \& Nickerson, N.P. (2006). Collecting and using visitor spending data. Journal of Travel Research, 45(1), pp. 17-25. 